\section{Factors Affecting Vegetative Propagation of Wintersweet (Chimonanthus praecox) by Softwood Cuttings}

\author{
Huan Hu, Nan Chai, Haoxiang Zhu, Rui Li, Renwei Huang, Xia Wang, \\ Daofeng Liu, and Mingyang Li \\ College of Horticulture and Landscape Architecture, Southwest University, \\ Chongqing 400715, China
}

\section{Xingrong Song \\ Horticulture Research Institute of Sichuan Academy of Agricultural Sciences, Key Laboratory of Horticultural Crops Biology and Germplasm Enhancement in Southwest of Ministry of Agriculture, Chengdu 610066, China \\ Shunzhao Sui \\ College of Horticulture and Landscape Architecture, Southwest University, Chongqing 400715, China}

Additional index words. hormone, medium, orthogonal design, rooting percentage, soaking duration, sprouting

\begin{abstract}
Wintersweet (Chimonanthus praecox) is one of the most popular winter-blooming species. Effective vegetative propagation is necessary for commercial usage and protection of wintersweet. In the current study, the four factors, namely hormone type (A), hormone concentration (B), soaking duration (C), and medium (D), were assessed using an $\mathrm{L}_{16}\left(4^{4}\right)$ orthogonal test design. The hormone types include $A B T\left(A_{1}\right), \alpha$-naphthalene acetic acid (NAA) $\left(A_{2}\right)$, indole butyric acid (IBA) $\left(A_{3}\right)$, and indole-3-acetic acid (IAA) ( $\left.A_{4}\right)$; the hormone concentrations include $100 \mathrm{mg} \cdot \mathrm{L}^{-1}\left(B_{1}\right), 500 \mathrm{mg} \cdot \mathrm{L}^{-1}\left(B_{2}\right), 1000 \mathrm{mg} \cdot \mathrm{L}^{-1}\left(B_{3}\right)$, and 1500 $\mathrm{mg} \cdot \mathrm{L}^{-1}\left(\mathrm{~B}_{4}\right)$; the soaking durations include 5 seconds $\left(C_{1}\right), 5$ minutes $\left(C_{2}\right), 30$ minutes $\left(C_{3}\right)$, and 3 hours $\left(C_{4}\right)$; and the mediums include perlite: peat in the ratios 1:0 $\left(D_{1}\right), 2: 1\left(D_{2}\right), 1: 1\left(D_{3}\right)$, and 1:2 $\left(\mathrm{D}_{4}\right)$. The results showed that hormone and proper medium could significantly improve the cutting survival, rooting, and sprouting, whereas poor factor combinations, especially high hormone concentrations combined with long soaking durations may be threatened to the cuttings and rooting. In actual experiments, we successfully obtained an excellent rooting percentage $(62.22 \%)$ of wintersweet from treatment No. $5\left(A_{2} B_{1} C_{2} D_{3}\right)$, which is perlite and peat (1:1) as the medium and soaking the cuttings in $100 \mathrm{mg} \cdot \mathrm{L}^{-1} \mathrm{NAA}$ for 5 minutes as the hormone treatment. This combination can already meet the requirements for commercial production. $A$ range analysis showed that the medium and hormone concentration were the most important factors affecting the cutting of wintersweet. An analysis of variance also showed that the medium and hormone concentration can significantly or extremely significantly affect most cutting indicators. Moreover, our results revealed that an orthogonal design method is an effective tool for establishing an improved technique for cutting propagation.
\end{abstract}

Chimonanthus praecox (L.) Link, Calycanthaceae, commonly known as "wintersweet" is a short deciduous ornamental shrub bearing sweet yellow flowers in winter and is

Received for publication 6 July 2020. Accepted for publication 11 Sept. 2020.

Published online 19 October 2020.

This work was supported by National Natural Science Foundation of China (Grant no. 31971711), and the Chongqing Science and Technology Bureau (cstc2018jscx-mszdX0004).

H.H. and N.C. contributed equally to this article.

X.S. and S.S. are the corresponding authors. E-mail: sszcq@swu.edu.cn or songxr98@163. com.

This is an open access article distributed under the CC BY-NC-ND license (https://creativecommons. org/licenses/by-nc-nd/4.0/).
(Dai et al., 2012). It is also one of the most precious relict species that can be traced back to the Tertiary period, and it is listed in the second class of endangered plants on the Red List of China (Tang and Tian, 2010). Therefore, the species must be reproduced because of its vast usage areas and protection requirements. Wintersweet is mainly propagated by seeding and stem cutting, with a period of 2 to 3 years from seed sowing to flowering (Chen and Chen, 2010). As the most economical vegetative propagation method, cutting can obtain large-scale saplings that not only are genetically consistent with the mother plants but also have a short seedling cycle, low cost, extensive source of reproductive materials, and easy seedling cultivation, which is a promising alternative means of expanding the endangered tree species (Guimaraes et al., 2019). Nevertheless, wintersweet cuttings are difficult to root, and the rooting percentage is generally less than $10 \%$ (Liu et al., 2001).

The cutting roots will be affected by a variety of endogenous and environmental factors such as tree species or varieties, the ability of cuttings to regenerate, carbohydrates, mineral salts, plant growth regulators (especially auxin), and the temperature, humidity, light, and rooting medium in the rooting environment of cuttings (Hechmi et al., 2013). Cuttings can be separated into nonlignified or softwood cuttings (newly grown branches with green color), lignified or semihardwood cuttings (partially matured and slightly woody branches with brown color), and hardwood cuttings (fully matured brownish and woody branches). Softwood cutting is the use of green branches during spring or summer for cuttings, and its use can significantly improve the rooting percentage and root quality of many woody species such as cherry (Gulen et al., 2004), cashew (Saranga and Cameron, 2007), and 'Tetraploid Locust' (Ling et al., 2013).

The exogenous application of rooting hormones is essential for good rooting in many difficult-to-root woody species (Kareem et al., 2013). A number of studies on adventitious root formation have shown that auxins play a fundamental role in the induction and development of roots (Doungous et al., 2019). The basal ends of cuttings are commonly dipped in plant growth regulators, such as IBA, IAA, and NAA for this purpose (Fogaca and FettNeto, 2005). ABT (contains 20\% NAA and $30 \%$ IAA) is a rooting promoter designed for difficult-to-root species by researchers at the Chinese Academy of Forestry, and it has been used as a hormone in many experiments ( $\mathrm{Li}$ et al., 2018a; Shi et al., 2019). Generally, exogenous hormones increase the rooting percentages of softwood cuttings (Justamante et al., 2017). However, the optimal concentration and soaking duration of the hormone required for each plant species depend on many factors, such as the cutting type, age, genotype, and species (Zhao et al., 2014). To date, an optimal treatment combination has not been developed that can 
be applied for the large-scale production of wintersweet cuttings.

Another vital factor for rooting induction is the rooting medium. When the rooting medium contains a supportive environment that includes good aeration, sufficient nutrients, and proper water, root system development is facilitated, which makes the plant grow well (Akram et al., 2017; Ara and Ishtiaq, 2001). Perlite and peat are often used as media. Perlite is widely used in the rooting of plants for its excellent moisture retention, aeration, and lightweight characteristics and sterility. Peat is an organic material commonly used in greenhouse cultivation, floriculture, seedling production, and similar horticultural works in many countries of the world (Bayraktar et al., 2018). To date, studies on the medium of wintersweet cutting are lacking.

Considering all the preceding issues, the softwood branches of wintersweet were used as the cuttings in this study. Based on previous studies on the cutting of wintersweet, the hormone type, hormone concentration, soaking duration, and medium were taken as the main factors affecting cutting propagation. Through orthogonal experiments, our work aimed to better understand the effects of various factors on cutting propagation and explore the environmental conditions suitable for rooting and root quality improvement as well as the best treatment combination.

\section{Materials and Methods}

Study site. The study was conducted in the greenhouse of Southwest University (lat. $29^{\circ} 83^{\prime} \mathrm{N}$, long. $106^{\circ} 43^{\prime} \mathrm{E}$, and altitude $360 \mathrm{~m}$, Beibei District, Chongqing City, China) from May to Dec. 2019. Chongqing has a subtropical monsoon humid climate. The 2019 monthly temperatures of the Chongqing area are shown in Fig. 1.

Collection and preparation of plant materials. Softwood branches (longer than $10 \mathrm{~cm}$ ) were taken from 10 strains of mature wintersweet (plants were $\geq 10$ years old) on the campus of Southwest University on 24 May 2019. The branches were collected in the morning to avoid dehydration of the leaf and subsequently cut into $10-$ to $15-\mathrm{cm} \mathrm{sec-}$ tions as cuttings (a bevel cut on the base and straight on top), each with two or three nodes carrying two or three pairs of leaves. Only one pair of leaves on the top was kept or trimmed by one-third to one-half, depending on the blade size, to reduce transpiration (Fig. 2A).

Experimental design. The experiments were carried out using four factors, namely, hormone type (A), hormone concentration (B), soaking duration (C), and medium (D), and each factor was set at four levels (Table 1). A total of 16 treatment combinations were established based on the $\mathrm{L}_{16}\left(4^{4}\right)$ orthogonal table (Table 2) (Muthukumaran et al., 2018). The blank control was based on perlite: peat $(1: 1)$ and soaked in water for 5 min. All 17 experiments had three indepen- dent replications $(\approx 30$ cuttings per replication).

Cutting and management. After the cutting process was finished, the basal ends were immersed in hormone to a depth of $\approx 2$ $\mathrm{cm}$. Ethanol (75\%) diluted with distilled water was used to dissolve the hormone. After hormone treatment, the cuttings were inserted in trays with 32 cells $(62 \mathrm{~mm}$ cell diameter, $55 \mathrm{~mm}$ cell depth) filled with medium. A small wooden rod was used to guide each hole before insertion to avoid damage to the cuttings at depths of 3 to 4 $\mathrm{cm}$, and one cutting was inserted in each cell (Fig. 2A).

The trays were then placed randomly on a shelf to avoid water accumulation. A fully automatic intermittent mist system was used to maintain the humidity and moisture of the greenhouse during the test. The mist was sprayed for $10 \mathrm{~s}$ every 2 to $3 \mathrm{~min}$ on sunny days and every $10 \mathrm{~min}$ on rainy days to maintain relative humidity above $70 \%$ and a temperature range from 20 to $35^{\circ} \mathrm{C}$. There were three layers of shade nets on the top of the greenhouse on hot days. To reduce contamination, defoliation on the seedbed was cleared in time, and carbendazim was sprayed at a dose of $1 \mathrm{mg} \cdot \mathrm{L}^{-1}$ once a week.

Data collection. After $120 \mathrm{~d}$ of testing, the cuttings were carefully removed from the rooting medium. The survival percentage (cuttings that maintained at least one original leaf or had no rot), rooting percentage (cuttings with at least $1 \mathrm{~mm}$ long roots), root number (only the roots that originated directly from the cuttings), and root length (average length of the longest root of each cutting) were investigated (Fig. 2A-C). All rooted cuttings were then transplanted to plastic pots filled with sand in the nursery. Their sprouting percentage (sprouted cuttings possessing new shoots or buds as a percentage of rooting cuttings), sprout length (average length of new shoots), and the sprout number (new shoots or buds that originated directly from the cuttings) were measured $75 \mathrm{~d}$ after transplanting (Fig. 2D)

Statistical analysis. Statistical analyses were conducted using Microsoft Excel 2016 (Redmond, WA) and SPSS version 23 (SPSS Inc., Chicago, IL) to assess the range and variance. All percentage data were subjected to arcsine transformation. Duncan's multiple range test was used for comparisons of different means of different treatments and different levels of factors when significant differences were obtained via analysis of variance (ANOVA).

\section{Results}

Survival percentage, root traits, and sprout traits. The survival percentage can reflect the damage degree caused by the hormone and environmental factors to the cuttings. Table 3 shows the survival percentage for each treatment, which ranged from $1.11 \%$ to $87.78 \%$ and averaged $62.90 \%$ over- all. Significant differences were observed in the survival percentage of cuttings between treatments. The survival percentages of treatment numbers $1 / 5 / 10 / 11 / 12 / 13 / 14 /$ 16 were significantly higher than that of the control.

The rooting percentage is the most important indicator to measure the success of cutting. The rooting percentages at $120 \mathrm{~d}$ after cutting are also shown in Table 3 . In this study, all treatments other than numbers 4 and 7 had adventitious root formation. Table 3 demonstrates that cuttings of wintersweet were challenging to root without hormone treatment, as the rooting percentage on the control was only $16.67 \%$. There was a significant difference in the rooting percentages of wintersweet between treatments. Compared with the control, treatment numbers $3 / 5 / 6 / 10 / 11 / 13 / 16$ significantly increased the rooting percentage. The average rooting percentage overall cutting treatments was $28.75 \%$. Treatment number 5 exhibited the highest rooting percentage, which was $62.22 \%$, and the factor combination $\mathrm{A}_{2} \mathrm{~B}_{1} \mathrm{C}_{2}$ $\mathrm{D}_{3}$ indicated that the medium was perlite and peat $(1: 1)$ and that the treatment included 100 $\mathrm{mg} \cdot \mathrm{L}^{-1} \mathrm{NAA}$ soaking for $5 \mathrm{~min}$.

A developed root system is the basis for robust growth of seedlings. The root number and root length are the essential indicators of the development of roots of cuttings. The results (Table 3 ) showed that treatments 4 and 7 lacked rooting, whereas the root numbers for the other treatments ranged from 1.00 to 9.12 , with an average number of 4.97; and the root length for each treatment ranged from 0.96 to $4.54 \mathrm{~cm}$, with an average length of $3.21 \mathrm{~cm}$. There was a significant difference in the two rooting traits of wintersweet between different treatments. The root numbers of treatments 6/9/ $10 / 11$ were significantly greater than that of the control. The root lengths of treatments $2 /$ $3 / 5 / 6 / 9 / 13 / 16$ were significantly longer than that of the control.

Sprouting is the ultimate embodiment of cutting success for wintersweet. The sprout traits at $75 \mathrm{~d}$ after transplanting in different treatments are also shown in Table 3 . The results showed, in addition to treatments 4 and 7 without transplant for no root formation, the sprouting percentage for other treatments ranged from $0 \%$ to $91.67 \%$, with an average of $67.83 \%$. Coupled with the death of cuttings of treatment 8 , the sprout length for other treatments ranged from 3.05 to $6.68 \mathrm{~cm}$, with an average length of $4.82 \mathrm{~cm}$; and the sprout number for other treatments ranged from 1.00 to 1.90 , with an overall average of 1.38. There was a significant difference in the sprouting percentage of wintersweet cuttings between different treatments. The sprouting percentages of treatments $6 / 10$ were significantly higher than that of the control. There was no significant difference in the sprout length and sprout numbers among all treatments except that the sprout length of treatment 16 was significantly higher than those of treatments 2 and 12 . 


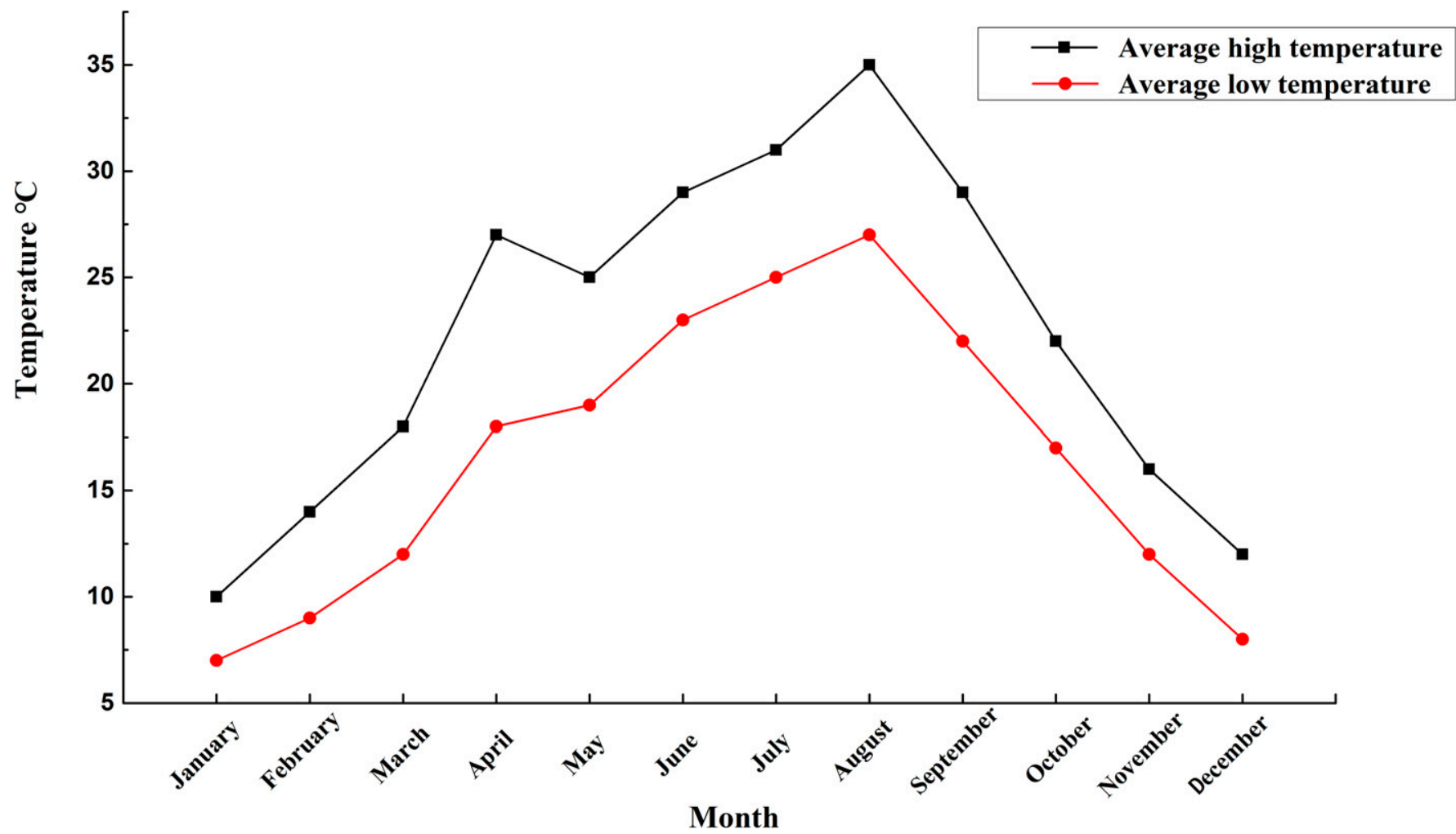

Fig. 1. The 2019 monthly temperatures of Chongqing.
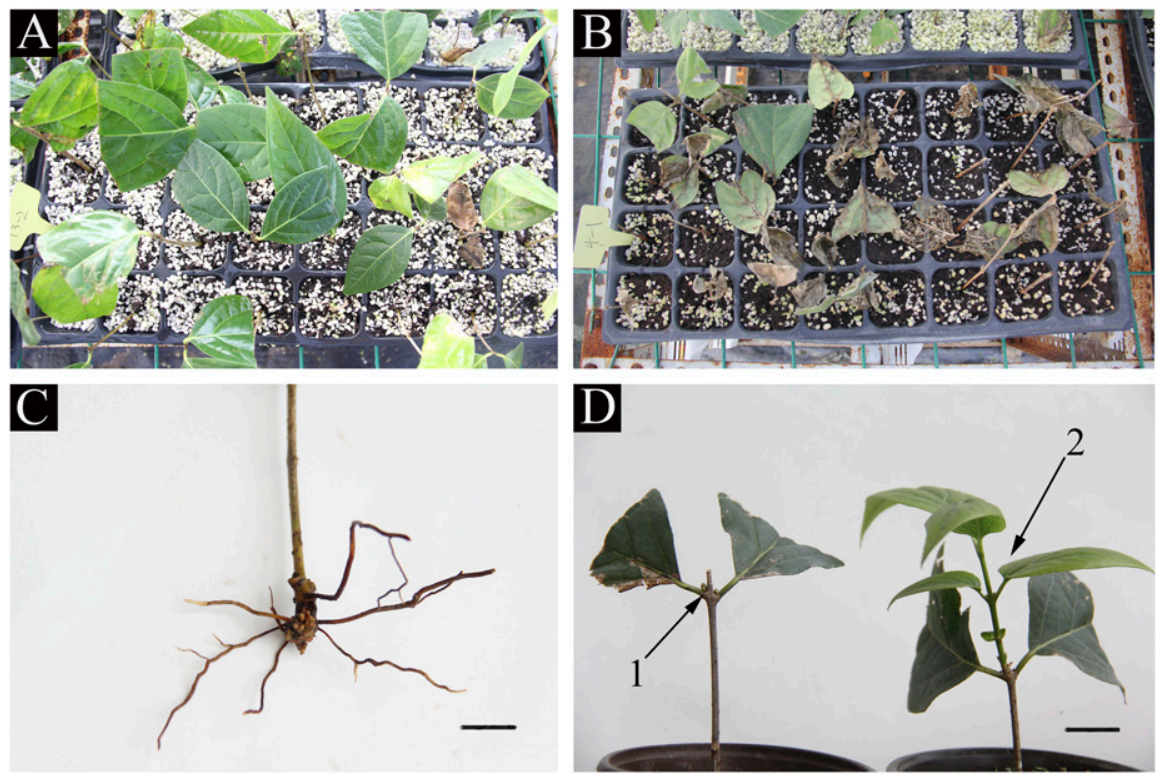

Fig. 2. Propagation of wintersweet from softwood cuttings. (A) Survival cuttings maintained healthy original leaves. (B) Dead cuttings performed defoliated or rotted. (C) Rooted cuttings. (D) Sprouted cuttings $(1=$ transfer-green buds, $2=$ new shoots $)$. Bars $=1 \mathrm{~cm}$.

Range analysis for survival percentage, root traits, and sprout traits. From the value of the range, the importance of the influence of each factor can be judged. As shown in Fig. 3, the factors affecting the survival percentage of wintersweet were hormone concentration $(\mathrm{R}=$ $31.36)>$ soaking duration $(\mathrm{R}=30.32)>$ hormone type $(\mathrm{R}=28.22)>$ medium $(\mathrm{R}=26.46)$.

The results of a range analysis of the root development indicators for $120 \mathrm{~d}$ after cutting are shown in Fig. 3. The factors affecting the rooting percentage, root numbers, and root length of cuttings were medium $(\mathrm{R}=32.80$, 4.59 , and 1.89 , respectively) $>$ hormone concentration $(\mathrm{R}=19.66,4.12$, and 1.47 , respectively) $>$ hormone type $(\mathrm{R}=18.86,2.64$, and 1.06 , respectively) $>$ soaking duration $(\mathrm{R}=$ $12.14,2.57$, and 0.64 , respectively).

The results of a range analysis of the sprout development indicators at $75 \mathrm{~d}$ after transplanting are also shown in Fig. 3. The order of factors affecting the sprouting percentage of wintersweet was hormone concentration $(\mathrm{R}=36.29)>$ medium $(\mathrm{R}=27.33)>$ soaking duration $(\mathrm{R}=22.85)>$ hormone type $(\mathrm{R}=13.29)$, whereas the factors affecting the sprout length were medium $(\mathrm{R}=2.49)>$ hormone type $(\mathrm{R}=1.31)>$ soaking duration $(\mathrm{R}=0.79)>$ hormone concentration $(\mathrm{R}=0.58)$ and the factors affecting the sprout number of wintersweet was hormone concentration $(\mathrm{R}=0.47)>$ medium $(\mathrm{R}=0.37)>$ hormone type $(\mathrm{R}=0.32)>$ soaking duration $(\mathrm{R}=0.18)$.

The theoretically optimal level of each factor can be determined according to the highest mean value obtained over the level tests for each factor. As shown in Fig. 3, the theoretically optimal factor combination for the survival percentage is $\mathrm{A}_{4} \mathrm{~B}_{1} \mathrm{C}_{1} \mathrm{D}_{3}$, which is perlite and peat $(1: 1)$ as the medium and soaking the cuttings with $100 \mathrm{mg} \cdot \mathrm{L}^{-1} \mathrm{IAA}$ for $5 \mathrm{~s}$ as the hormone treatment.

Similarly, the theoretically optimal factor combination for the rooting percentage is $A_{3} B_{1} C_{2} D_{3}$, which is perlite and peat $(1: 1)$ as the medium and soaking the cuttings with $100 \mathrm{mg} \cdot \mathrm{L}^{-1}$ IBA for $5 \mathrm{~min}$ as the hormone treatment; the optimal combination for the root number is $\mathrm{A}_{3} \mathrm{~B}_{2} \mathrm{C}_{4} \mathrm{D}_{4}$, which is perlite and peat $(1: 2)$ as the medium and soaking the cuttings with $500 \mathrm{mg} \cdot \mathrm{L}^{-1} \mathrm{IBA}$ for $3 \mathrm{~h}$ as the hormone treatment; and the optimal combination for the root length is $\mathrm{A}_{1} \mathrm{~B}_{3} \mathrm{C}_{4}$ $\mathrm{D}_{4}$, which is perlite and peat $(1: 2)$ as the medium and soaking the cuttings with 1000 $\mathrm{mg} \cdot \mathrm{L}^{-1} \mathrm{ABT}$ for $3 \mathrm{~h}$ as the hormone treatment. 
Table 1. Factors and their levels for wintersweet softwood cutting propagation.

\begin{tabular}{|c|c|c|c|c|}
\hline \multirow[b]{2}{*}{ Level } & \multicolumn{4}{|c|}{ Expt. factor } \\
\hline & Hormone type (A) & Hormone concn (B) & Soaking duration (C) & Medium (D) \\
\hline$\overline{1}$ & $\mathrm{ABT}$ & $100 \mathrm{mg} \cdot \mathrm{L}^{-1}$ & $5 \mathrm{~s}$ & perlite:peat $1: 0$ \\
\hline 2 & NAA & $500 \mathrm{mg} \cdot \mathrm{L}^{-1}$ & $5 \mathrm{~min}$ & perlite:peat $2: 1$ \\
\hline 3 & IBA & $1000 \mathrm{mg} \cdot \mathrm{L}^{-1}$ & $30 \mathrm{~min}$ & perlite:peat $1: 1$ \\
\hline 4 & IAA & $1500 \mathrm{mg} \cdot \mathrm{L}^{-1}$ & $3 \mathrm{~h}$ & perlite:peat $1: 2$ \\
\hline
\end{tabular}

Table 2. Design of the $\mathrm{L}_{16}\left(4^{4}\right)$ orthogonal experiment for cutting propagation of wintersweet.

\begin{tabular}{|c|c|c|c|c|c|c|c|c|}
\hline \multirow[b]{2}{*}{ Treatment no. } & \multicolumn{4}{|c|}{ Factor and level } & \multicolumn{4}{|c|}{ Corresponding treatment } \\
\hline & $\mathrm{A}$ & $\mathrm{B}$ & $\mathrm{C}$ & $\mathrm{D}$ & Hormone type & Hormone concn & Soaking duration & Medium \\
\hline$\overline{1}$ & 1 & 1 & 1 & 1 & ABT & $100 \mathrm{mg} \cdot \mathrm{L}^{-1}$ & $5 \mathrm{~s}$ & perlite:peat 1:0 \\
\hline 2 & 1 & 2 & 2 & 2 & $\mathrm{ABT}$ & $500 \mathrm{mg} \cdot \mathrm{L}^{-1}$ & $5 \mathrm{~min}$ & perlite:peat $2: 1$ \\
\hline 3 & 1 & 3 & 3 & 3 & $\mathrm{ABT}$ & $1000 \mathrm{mg} \cdot \mathrm{L}^{-1}$ & $30 \mathrm{~min}$ & perlite:peat $1: 1$ \\
\hline 4 & 1 & 4 & 4 & 4 & $\mathrm{ABT}$ & $1500 \mathrm{mg} \cdot \mathrm{L}^{-1}$ & $3 \mathrm{~h}$ & perlite:peat $1: 2$ \\
\hline 5 & 2 & 1 & 2 & 3 & NAA & $100 \mathrm{mg} \cdot \mathrm{L}^{-1}$ & $5 \mathrm{~min}$ & perlite:peat $1: 1$ \\
\hline 6 & 2 & 2 & 1 & 4 & NAA & $500 \mathrm{mg} \cdot \mathrm{L}^{-1}$ & $5 \mathrm{~s}$ & perlite:peat $1: 2$ \\
\hline 7 & 2 & 3 & 4 & 1 & NAA & $1000 \mathrm{mg} \cdot \mathrm{L}^{-1}$ & $3 \mathrm{~h}$ & perlite:peat $1: 0$ \\
\hline 8 & 2 & 4 & 3 & 2 & NAA & $1500 \mathrm{mg} \cdot \mathrm{L}^{-1}$ & $30 \mathrm{~min}$ & perlite:peat $2: 1$ \\
\hline 9 & 3 & 1 & 3 & 4 & IBA & $100 \mathrm{mg} \cdot \mathrm{L}^{-1}$ & $30 \mathrm{~min}$ & perlite:peat $1: 2$ \\
\hline 10 & 3 & 2 & 4 & 3 & IBA & $500 \mathrm{mg} \cdot \mathrm{L}^{-1}$ & $3 \mathrm{~h}$ & perlite:peat $1: 1$ \\
\hline 11 & 3 & 3 & 1 & 2 & IBA & $1000 \mathrm{mg} \cdot \mathrm{L}^{-1}$ & $5 \mathrm{~s}$ & perlite:peat $2: 1$ \\
\hline 12 & 3 & 4 & 2 & 1 & IBA & $1500 \mathrm{mg} \cdot \mathrm{L}^{-1}$ & $5 \mathrm{~min}$ & perlite:peat $1: 0$ \\
\hline 13 & 4 & 1 & 4 & 2 & IAA & $100 \mathrm{mg} \cdot \mathrm{L}^{-1}$ & $3 \mathrm{~h}$ & perlite:peat $2: 1$ \\
\hline 14 & 4 & 2 & 3 & 1 & IAA & $500 \mathrm{mg} \cdot \mathrm{L}^{-1}$ & $30 \mathrm{~min}$ & perlite:peat $1: 0$ \\
\hline 15 & 4 & 3 & 2 & 4 & IAA & $1000 \mathrm{mg} \cdot \mathrm{L}^{-1}$ & $5 \mathrm{~min}$ & perlite:peat $1: 2$ \\
\hline 16 & 4 & 4 & 1 & 3 & IAA & $1500 \mathrm{mg} \cdot \mathrm{L}^{-1}$ & $5 \mathrm{~s}$ & perlite:peat $1: 1$ \\
\hline
\end{tabular}

As shown in Fig. 3, the theoretically optimal factor combination for the sprouting percentage after transplanting is $\mathrm{A}_{3} \mathrm{~B}_{2} \mathrm{C}_{4} \mathrm{D}_{4}$, which is perlite and peat (1:2) as the medium and soaking the cuttings with $500 \mathrm{mg} \cdot \mathrm{L}^{-1}$ IBA for $3 \mathrm{~h}$ as the hormone treatment; the optimal combination for the sprout length is $\mathrm{A}_{2} \mathrm{~B}_{4} \mathrm{C}_{1} \mathrm{D}_{3}$, which is perlite and peat $(1: 1)$ as the medium and soaking the cuttings with $1500 \mathrm{mg} \cdot \mathrm{L}^{-1} \mathrm{NAA}$ for $5 \mathrm{~s}$ as the hormone treatment; and the optimal combination for the sprout number is $\mathrm{A}_{4} \mathrm{~B}_{3} \mathrm{C}_{3} \mathrm{D}_{2}$, which is perlite and peat $(2: 1)$ as the medium and soaking the cuttings with $1000 \mathrm{mg} \cdot \mathrm{L}^{-1}$ IAA for $30 \mathrm{~min}$ as the hormone treatment.

Variance analysis and multiple comparisons for survival percentage, root traits, and sprout traits. The range analysis can reflect the test result simply and visually, although it does not reflect the error range and accuracy; therefore, an ANOVA is also needed (Table 4). The results of a variance analysis of all indicators under different test factors and levels showed that hormone type (A) had an extremely significant effect on the survival percentage and rooting percentage. The hormone concentration (B) had a significant effect on the root number and root length and had an extremely significant effect on the survival percentage, rooting percentage, and sprouting percentage. Varying the soaking duration (C) caused a significant difference in the rooting percentage and sprouting percentage and an extremely significant difference in the survival percentage. Varying the medium (D) caused a significant difference in the root number and sprouting percentage and an extremely significant difference in the survival percentage, rooting percentage, root length, and sprout length.
Multiple comparisons were conducted between the mean values of factors that significantly affected the survival percentage (Table 5). The survival percentages of cuttings treated with IBA and IAA were significantly higher than those of cuttings treated with $\mathrm{ABT}$ and NAA, and there were no significant differences between the survival percentages for IBA and IAA. The survival percentages of the cuttings treated with the concentration of $100 \mathrm{mg} \cdot \mathrm{L}^{-1}$ were significantly higher than those of cuttings treated with $500 / 1000 / 1500 \mathrm{mg} \cdot \mathrm{L}^{-1}$, and there were no significant differences among the latter three. The survival percentages of cuttings with $5 \mathrm{~s}, 5 \mathrm{~min}$, and $30 \mathrm{~min}$ soaking duration were significantly higher than that of cuttings soaked for $3 \mathrm{~h}$, and there were no significant differences among the former three. The survival percentages of cuttings with a medium of perlite:peat $(1: 1)$ were significantly higher than those with $2: 1$ or $1: 2$, and there were no significant differences between these percentages for 1:1 and 1:0.

Multiple comparisons were conducted between the mean values of factors that significantly affected only the root traits (Table 5). The rooting percentages of cuttings treated with IBA and IAA were significantly higher than those of treated by $\mathrm{ABT}$, and there were no significant differences between the rooting percentage for IBA and IAA. The rooting percentages of the cuttings treated with $100 / 500 / 1000 \mathrm{mg} \cdot \mathrm{L}^{-1}$ were significantly higher than those with $1500 \mathrm{mg} \cdot \mathrm{L}^{-1}$, and there were no significant differences among those of the former three. The rooting percentages of cuttings soaked for 5 min were significantly higher than those soaked for $30 \mathrm{~min}$ and $3 \mathrm{~h}$, and there were no significant differences between the values for $5 \mathrm{~s}$ and $5 \mathrm{~min}$.
The rooting percentages of cuttings with a medium of perlite:peat (1:1) were significantly higher than those with the other three ratios. The root numbers of cuttings treated with $500 / 1000 \mathrm{mg} \cdot \mathrm{L}^{-1}$ were significantly higher than that with $1500 \mathrm{mg} \cdot \mathrm{L}^{-1}$, and there were no significant differences among the values for $100 / 500 / 1000 \mathrm{mg} \cdot \mathrm{L}^{-1}$. The root lengths of cuttings treated with a concentration of $100 / 500 / 1000 \mathrm{mg} \cdot \mathrm{L}^{-1}$ were significantly higher than that for $1500 \mathrm{mg} \cdot \mathrm{L}^{-1}$, and there were no significant differences among those of the former three. The root numbers and the root lengths of cuttings with a medium of perlite: peat $(2: 1,1: 1$, and $1: 2)$ were significantly higher than those with $1: 0$, and there were no significant differences among the former three.

Multiple comparisons were also conducted between different levels of factors significantly affecting only the sprouting percentage and sprout length (Table 5). The sprouting percentage of cuttings treated with $100 / 500 / 1000 \mathrm{mg} \cdot \mathrm{L}^{-1}$ were significantly higher than that with $1500 \mathrm{mg} \cdot \mathrm{L}^{-1}$, and no significant differences were observed among the former three. The sprouting percentages of cuttings soaked for $5 \mathrm{~s}$ and $3 \mathrm{~h}$ were significantly higher than that for $30 \mathrm{~min}$, and no significant differences were observed among the values for $5 \mathrm{~s}, 5 \mathrm{~min}$, and $3 \mathrm{~h}$ soakings. The sprouting percentages of cuttings with mediums of perlite:peat $(1: 1$ and $1: 2$ ) were significantly higher than those with $1: 0$ and $2: 1$, and no significant differences were observed between the values for the former two. The sprout lengths of cuttings with a medium of perlite: peat (1:1) were significantly higher than those with 1:0 and $2: 1$, and there were no significant differences between the values for $1: 1$ and 1:2. 


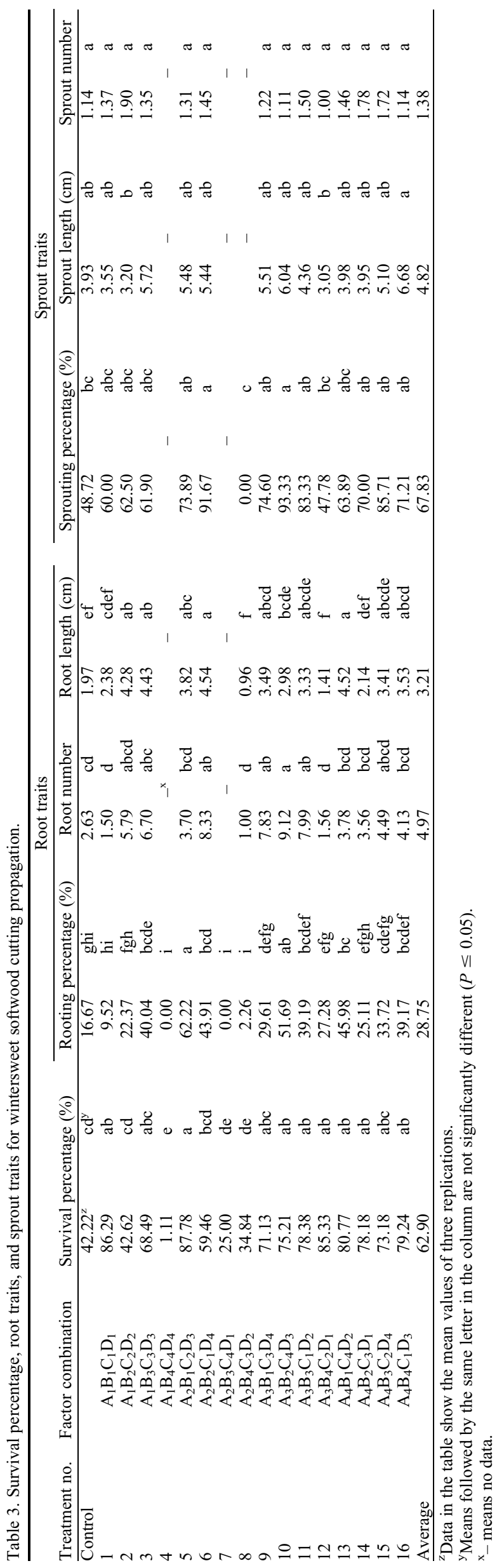

\section{Discussion}

Rooting percentage and survival percentage. Wintersweet belongs to a difficult-to-root woody plant. The results of the present investigations indicate that it is possible to significantly improve survival, rooting, and sprouting of softwood cuttings of wintersweet with the application of hormones (Table 3). In our study, the rooting percentage of the control at $120 \mathrm{~d}$ after cutting was only $16.67 \%$ (Table 3 ), which was slightly higher than the rooting percentage of wintersweet in general without hormone treatment, as previously reported by peers. Liu et al. (2001) reported an 8\% rooting percentage when using semihardwood or hardwood treated with distilled water as cuttings in the middle of August. The differences between their results and ours may be because of the use of greensoftwood as cuttings at the end of May, a timed spray device to keep the environment moist, and just the most appropriate medium for root formation in our test. For softwood cutting, the meristem is active, photosynthesis is vigorous, more auxin is synthesized, and few substances block the root. Harfouche et al. (2007) claimed that summer is the best period for poplar cuttings to take root because the donor plants are in optimal physiological condition for vegetative propagation. According to Saranga and Cameron (2007), hard-to-root species may tend to root easily when external conditions are suitable. A mist system is useful to reduce water stress during root formation (Shibuya et al., 2013; Stefancic et al., 2007). Further studies are also needed to understand why wintersweet consistently roots poorly.

Some treatments had a lower survival percentage and rooting percentage and even no root formation (Table 3), indicating that poor factor combinations, especially high hormone concentrations combined with long soaking durations, may damage cuttings and inhibit rooting. Figure 3 also intuitively reflects that the survival percentage of cuttings decreased sharply with increasing hormone concentration or soaking duration. Too high a concentration of exogenous hormones and/ or too long of a soaking duration may inhibit root formation in cuttings and even lead to the death of the cuttings (Zhao et al., 2014). Doungous et al. (2019) and van Telgen et al. (2007) claimed that at a certain level, hormones may have a toxic effect on cuttings. Mori et al. (2011) also reported that some cuttings soaked for $1 \mathrm{~h}$ died or were damaged in the normal elongation of apical buds, whereas this phenomenon was not observed in cuttings soaked for $5 \mathrm{~s}$ or $10 \mathrm{~min}$.

The main manifestation of cutting death is commonly defoliation, followed by tissue necrosis and decay (Fig. 2B). The presence of leaves is necessary for the production of auxins, which are transported to the base of cuttings and contribute to new root formation (Tarrago et al., 2005; Thomas and Schiefelbein, 2004). In fact, the formation of adventitious roots in turn prevents 

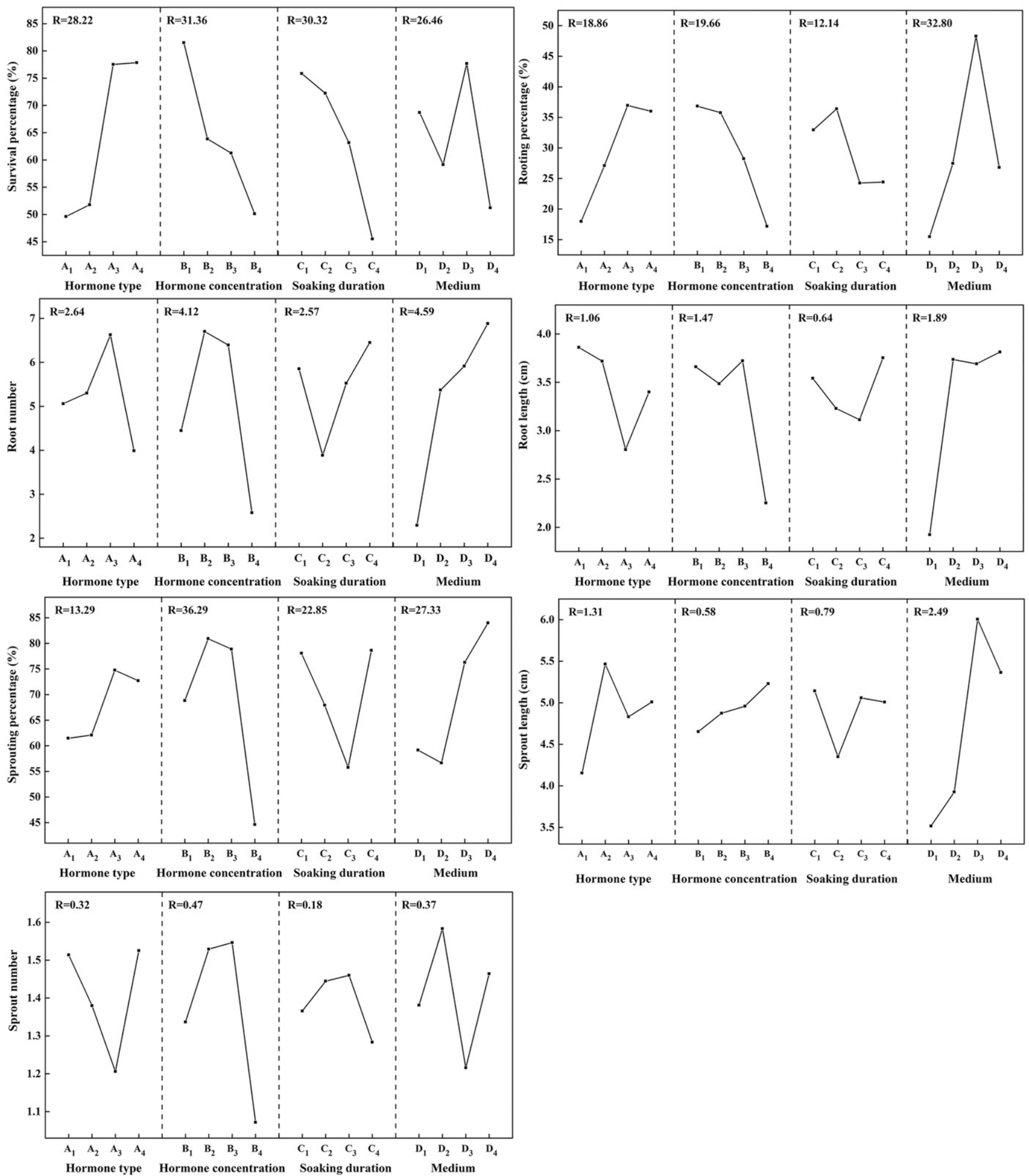

Fig. 3. Relationships between the mean values of each factor at each level for the survival percentage, root traits, and sprout traits. The range $\mathrm{R}$ is the difference between the maximum and minimum value for each factor. The largest mean value for the factor can be considered that this level is most optimal for this factor.

cuttings from being exposed to suboptimal environments or reduces pathogen activity associated with such environments (Saranga and Cameron, 2007), and prevent cuttings from rotting and defoliation, thereby reducing the death of cuttings. Simultaneously, correlation analysis also showed an ex- tremely significant correlation between the rooting percentage and survival percentage for softwood cuttings of wintersweet (data not shown).

Range analysis for factors. The range analysis showed that among the four factors affecting softwood cuttings of wintersweet, the medium is the most important factor affecting the rooting percentage, root number, root length, and sprout length (Fig. 3). The medium and physical properties determine the rooting environment. The ideal rooting medium should have the best porosity to meet oxygen diffusion and air exchange 
Table 4. Variance analysis to determine the influence of various factors on the survival percentage, root traits, and sprout traits of wintersweet softwood cutting propagation based on the $\mathrm{L}_{16}\left(4^{4}\right)$ orthogonal design.

\begin{tabular}{|c|c|c|c|c|c|c|c|c|c|c|c|c|c|c|}
\hline \multirow[b]{2}{*}{ Source } & \multicolumn{2}{|c|}{ Survival percentage } & \multicolumn{2}{|c|}{ Rooting percentage } & \multicolumn{2}{|c|}{ Root number } & \multicolumn{2}{|c|}{ Root length } & \multicolumn{2}{|c|}{ Sprouting percentage } & \multicolumn{2}{|c|}{ Sprout length } & \multicolumn{2}{|c|}{ Sprout number } \\
\hline & $F$ & $P$ & $F$ & $P$ & $F$ & $P$ & $F$ & $P$ & $F$ & $P$ & $F$ & $P$ & $F$ & $P$ \\
\hline Hormone type (A) & 8.799 & $0.000^{* *}$ & 7.404 & $0.001 * *$ & 1.396 & 0.260 & 1.646 & 0.196 & 2.533 & 0.080 & 0.413 & 0.745 & 1.043 & 0.386 \\
\hline $\begin{array}{l}\text { Hormone } \\
\text { concentration (B) }\end{array}$ & 6.094 & $0.002 * *$ & 7.734 & $0.000 * *$ & 3.641 & $0.022 *$ & 2.985 & $0.044 *$ & 6.666 & $0.002 * *$ & 0.155 & 0.926 & 1.693 & 0.188 \\
\hline $\begin{array}{l}\text { Soaking } \\
\text { duration (C) }\end{array}$ & 6.627 & $0.001 * *$ & 3.539 & $0.024 *$ & 1.159 & 0.339 & 0.473 & 0.703 & 3.776 & $0.023 *$ & 0.243 & 0.866 & 0.208 & 0.890 \\
\hline Medium (D) & 4.771 & $0.007 * *$ & 17.587 & $0.000 * *$ & 3.916 & $0.016^{*}$ & 7.536 & $0.001 * *$ & 3.452 & $0.032 *$ & 5.707 & $0.004 * *$ & 1.043 & 0.386 \\
\hline
\end{tabular}

*Indicates that the experimental factor was significant at the $P \leq 0.05$ level.

** Indicates that the experimental factor was extremely significant at the $P \leq 0.01$ level.

Table 5. Multiple comparisons of the effects of different factors and levels on the survival percentage, root traits, and sprout traits of wintersweet softwood cutting propagation.

\begin{tabular}{|c|c|c|c|c|c|c|c|c|}
\hline \multirow[b]{2}{*}{ Factors } & \multirow[b]{2}{*}{ Level } & \multirow{2}{*}{$\begin{array}{c}\text { Survival } \\
\text { percentage } \\
(\%)\end{array}$} & \multicolumn{3}{|c|}{ Root traits } & \multicolumn{3}{|c|}{ Sprout traits } \\
\hline & & & $\begin{array}{c}\text { Rooting } \\
\text { percentage }(\%)\end{array}$ & $\begin{array}{c}\text { Root } \\
\text { number }\end{array}$ & $\begin{array}{c}\text { Root } \\
\text { length }(\mathrm{cm})\end{array}$ & $\begin{array}{c}\text { Sprouting } \\
\text { percentage }(\%)\end{array}$ & $\begin{array}{c}\text { Sprout } \\
\text { length }(\mathrm{cm})\end{array}$ & Sprout number \\
\hline \multirow[t]{4}{*}{ Hormone type (A) } & ABT & $49.63^{\mathrm{z}} \mathrm{b}^{\mathrm{y}}$ & $17.98 \mathrm{c}$ & $-^{\mathrm{x}}$ & - & - & - & - \\
\hline & NAA & $51.77 \mathrm{~b}$ & $27.10 \mathrm{bc}$ & - & - & - & - & - \\
\hline & IBA & $77.51 \mathrm{a}$ & $36.94 \mathrm{a}$ & - & - & - & - & - \\
\hline & IAA & $77.84 \mathrm{a}$ & $35.99 \mathrm{ab}$ & - & - & - & - & - \\
\hline \multirow{4}{*}{$\begin{array}{l}\text { Hormone } \\
\text { concentration (B) }\end{array}$} & $100 \mathrm{mg} \cdot \mathrm{L}^{-1}$ & $81.49 \mathrm{a}$ & $36.83 \mathrm{a}$ & $4.45 \mathrm{ab}$ & $3.66 \mathrm{a}$ & $68.83 \mathrm{a}$ & - & - \\
\hline & $500 \mathrm{mg} \cdot \mathrm{L}^{-1}$ & $63.87 \mathrm{~b}$ & $35.77 \mathrm{a}$ & $6.70 \mathrm{a}$ & $3.49 \mathrm{a}$ & $80.91 \mathrm{a}$ & - & - \\
\hline & $1000 \mathrm{mg} \cdot \mathrm{L}^{-1}$ & $61.26 \mathrm{~b}$ & $28.24 \mathrm{a}$ & $6.39 \mathrm{a}$ & $3.72 \mathrm{a}$ & $78.87 \mathrm{a}$ & - & - \\
\hline & $1500 \mathrm{mg} \cdot \mathrm{L}^{-1}$ & $50.13 b$ & $17.18 \mathrm{~b}$ & $2.58 \mathrm{~b}$ & $2.25 \mathrm{~b}$ & $44.62 \mathrm{~b}$ & - & - \\
\hline \multirow[t]{4}{*}{ Soaking duration (C) } & $5 \mathrm{~s}$ & $75.84 \mathrm{a}$ & $32.95 \mathrm{ab}$ & - & - & $78.06 \mathrm{a}$ & - & - \\
\hline & $5 \mathrm{~min}$ & $72.23 \mathrm{a}$ & $36.40 \mathrm{a}$ & - & - & $67.92 \mathrm{ab}$ & - & - \\
\hline & $30 \mathrm{~min}$ & $63.16 \mathrm{a}$ & $24.26 \mathrm{~b}$ & - & - & $55.76 \mathrm{~b}$ & - & - \\
\hline & $3 \mathrm{~h}$ & $45.52 \mathrm{~b}$ & $24.42 \mathrm{~b}$ & - & - & $78.61 \mathrm{a}$ & - & - \\
\hline \multirow[t]{4}{*}{ Medium (D) } & $1: 0$ & $68.70 \mathrm{ab}$ & $15.48 \mathrm{c}$ & $2.30 \mathrm{~b}$ & $1.92 \mathrm{~b}$ & $59.17 \mathrm{~b}$ & $3.52 \mathrm{c}$ & - \\
\hline & $2: 1$ & $59.15 \mathrm{bc}$ & $27.45 \mathrm{~b}$ & $5.37 \mathrm{a}$ & $3.74 \mathrm{a}$ & $56.67 \mathrm{~b}$ & $3.93 \mathrm{bc}$ & - \\
\hline & $1: 1$ & $77.68 \mathrm{a}$ & $48.28 \mathrm{a}$ & $5.91 \mathrm{a}$ & $3.69 \mathrm{a}$ & $76.28 \mathrm{a}$ & $6.00 \mathrm{a}$ & - \\
\hline & $1: 2$ & $51.22 \mathrm{c}$ & $26.81 \mathrm{~b}$ & $6.88 \mathrm{a}$ & $3.81 \mathrm{a}$ & $83.99 \mathrm{a}$ & $5.36 \mathrm{ab}$ & - \\
\hline
\end{tabular}

${ }^{\mathrm{z}}$ Data in the table show the mean values of factors at each level.

${ }^{\mathrm{y}}$ Means followed by the same letter in the column are not significantly different at the $5 \%$ level of significance.

${ }^{x}$ - means that the factor has no significant impact on the indicator.

needs (Amri, 2012; Amri et al., 2009). In our research, we found that the best medium for the survival percentage, rooting percentage, and sprout length for cutting propagation of wintersweet was perlite:peat (1:1) (Fig. 3). Ercisli et al. (2002) found that the highest rooting percentage for kiwifruit hardwood cuttings was obtained in perlite:peat $(1: 1)$, whereas Denny and Arnold (2001) found that the best the rooting percentage for cuttings of American smoketree (Cotinus obovatus) obtained with perlite:peat (1:0). Exadaktylou et al. (2009) reported no significant difference on the rooting percentage of the 'Gisela 5 ' cherry hardwood cuttings between perlite:peat (1:1) and (1:0), both of which were better media than sand, peat, and vermiculite.

The range analysis also showed that hormone concentration is the most important factor affecting the survival percentage, sprouting percentage, and sprout number (Fig. 3). Regardless of the influence of the medium, interestingly, the factor that most influenced all variables except the sprout length was hormone concentration, followed by hormone type and soaking duration. The most important reason for successful cutting propagation of difficult-to-root plants was the use of the correct concentration of the hormone, which increased the root development (Sulusoglu and Cavusoglu, 2010). In our study, treatment of wintersweet cuttings with hormone suggested that its application could increase the survival percentage and rooting percentage at low concentrations $\left(100 \mathrm{mg} \cdot \mathrm{L}^{-1}\right)$ (Fig. 3). Liu et al. (2001) soaked the semihardwood cuttings of wintersweet with IBA, IAA, and NAA at a lower concentration $\left(50 \mathrm{mg} \cdot \mathrm{L}^{-1}\right)$ for $24 \mathrm{~h}$ and obtained rooting percentages of $52.9 \%, 34.6 \%$, and $54.0 \%$, respectively.

Orthogonal experiments. The orthogonal design method has been used widely and successfully, although despite its frequent usage, it has been less used in agriculture (Rao et al., 2008; Sadr et al., 2019). The primary advantages of using orthogonal designs for testing are that they are much more efficient than studying one variable at a time, cost-efficient, and much simpler than full factorial designs (Ranil et al., 2015). Only a few studies have used orthogonal design to improve rooting percentage in other species by studying three or four factors (Li et al., 2018a). In the present study, if a traditional full factorial design was performed to examine the effects of four factors, each at four levels, then a total of $256\left(4^{4}\right)$ treatments would be required. The orthogonal design method required only 16 treatments, which is obviously reasonable for reducing the number of trials while providing considerable information. For the first time, orthogonal experiments were used to study the factors affecting softwood cutting of wintersweet.
In our study, we have successfully obtained an excellent rooting percentage $(62.22 \%)$ for wintersweet with treatment 5 $\left(\mathrm{A}_{2} \mathrm{~B}_{1} \mathrm{C}_{2} \mathrm{D}_{3}\right)$, which was slightly different from the theoretically optimal factor combination $\left(\mathrm{A}_{3} \mathrm{~B}_{1} \mathrm{C}_{2} \mathrm{D}_{3}\right)$ in terms of the hormone type $\left(\mathrm{A}_{2}\right.$ and $\left.\mathrm{A}_{3}\right)$, and the combinations already meet the requirements for commercial production. It is worth noting that the rooting percentage and survival percentage of hormone type $\mathrm{A}_{2}$ were significantly lower than those for $\mathrm{A}_{3}$ in the present study (Table 5), which imply that there is still great potential for cuttage rooting of wintersweet.

The slight differences in results between the theoretically optimal factor combination from the range analysis (Fig. 3) and the actual best treatment combination in our experiments (Table 3) were also reflected in the root numbers $\left(\mathrm{A}_{3} \mathrm{~B}_{2} \mathrm{C}_{4} \mathbf{D}_{3}\right.$ and $\left.\mathrm{A}_{3} \mathrm{~B}_{2} \mathrm{C}_{4} \mathbf{D}_{4}\right)$ and sprout length $\left(\mathbf{A}_{\mathbf{4}} \mathrm{B}_{4} \mathrm{C}_{1} \mathrm{D}_{3}\right.$ and $\mathbf{A}_{\mathbf{2}} \mathrm{B}_{4} \mathrm{C}_{1}$ $\mathrm{D}_{3}$ ), which confirms to some extent the feasibility of the orthogonal design. Our results show that the orthogonal design method is a robust, simple, and powerful tool for contemporaneously studying the primary effects of multiple factors to improve cutting protocols in difficult-to-root horticultural species. In the future, based on the presented information, the optimal combination of factors obtained from this experiment needs to be further verified, optimized, and adjusted in a 
field trial to facilitate its future promotion and improve the vegetative reproduction efficiency of softwood cuttings of wintersweet.

However, many factors affect the rooting of plant cuttings. Because of limitations of time and space, this study cannot present the factors one by one. Follow-up research will also improve on the method and provide more in-depth results, thereby providing a more comprehensive and standardized technical system for the cutting and rapid propagation of wintersweet and its varieties.

\section{Literature Cited}

Akram, M.T., R.W.K. Qadri, I. Khan, M. Bashir, M.M. Jahangir, N. Nisar, and M.M. Khan. 2017. Clonal multiplication of Guava (Psidium guajava) through soft wood cuttings using IBA under low-plastic tunnel. Intl. J. Agr. Biol. 19:417-422, doi: 10.17957/IJAB/15.0172.

Amri, E., H. Lyaruu, A. Nyomora, and Z. Kanyeka. 2009. Evaluation of provenances and rooting media for rooting ability of African blackwood (Dalbergia melanoxylon Guill. \& Perr.) stem cuttings. Res. J. Agr. Biologic. Sci. 5:524-532. https://www.researchgate.net/publication/ 275019075.

Amri, E. 2012. The effect of auxins (IBA, NAA) on vegetative propagation of medicinal plant $B o b-$ gunnia madagascariensis (Desv.) J.H. Kirkbr \& Wiersema. Tanzania J. Natural Appl. Sci. 2:359-366. https://www.researchgate.net/publication/275018973.

Ara, N. and M. Ishtiaq. 2001. Response of Eucalyptus camaldulensis seedlings to different soil media. Sarhad J. Agr. 17:75-79. https://agris. fao.org/agris-search/search.do? recordID= PK2002000238.

Bayraktar, A., F. Atar, N. Yildirim, and I. Turna. 2018. Effects of different media and hormones on propagation by cuttings of european yew (Taxus baccata L.). Sumar. List 142:509-516, doi: 10.31298/sl.142.9-10.6.

Chen, D.W. and L.Q. Chen. 2010. The first intraspecific genetic linkage maps of wintersweet [Chimonanthus praecox (L.) Link] based on AFLP and ISSR markers. Scientia Hort. 124:88-94, doi: 10.1016/j.scienta.2009.12.008.

Dai, P.F., J. Yang, T.H. Zhou, Z.H. Huang, L. Feng, H.L. Su, Z.L. Liu, and G.F. Zhao. 2012. Genetic diversity and differentiation in Chimonanthus praecox and Ch. salicifolius (Calycanthaceae) as revealed by inter-simple sequence repeat (ISSR) markers. Biochem. Syst. Ecol. 44:149-156, doi: 10.1016/j.bse.2012.04.014.

Denny, C. and A. Arnold. 2001. Interactions among rooting substrate, phenological stage of cuttings and auxin concentration on the rooting of Cotinus obovatus. J. Appl. Hort. Lucknow. 1:13-16, doi: 10.37855/jah.2001.v03i01.02.

Doungous, O., E. Minyaka, S.D. Medza-Mve, A.F. Medueghue, M.A. Ngone, C. Simo, and A.M. Nsimi. 2019. Improving propagation methods of Gnetum africanum and G. buchholzianum from cuttings for rapid multiplication, domestication and conservation. Agrofor. Syst. 93:1557-1565, doi: 10.1007/s10457-018-0269-8.

Ercisli, S., O. Anapali, A. Esitken, and U. Sahin. 2002. The effects of IBA, rooting media and cutting collection time on rooting of kiwifruit. Gartenbauwissenschaf. 67:34-38. https://www. researchgate.net/publication/297910276.

Exadaktylou, E., T. Thomidis, B. Grout, G. Zakynthinos, and C. Tsipouridis. 2009. Methods to improve the rooting of hardwood cuttings of the
'Gisela 5' Cherry rootstock. HortTechnology 19:254-259, doi: 10.21273/Hortsci.19.2.254.

Fogaca, C.M. and A.G. Fett-Neto. 2005. Role of auxin and its modulators in the adventitious rooting of Eucalyptus species differing in recalcitrance. Plant Growth Regulat. 45:1-10, doi: 10.1007/s10725-004-6547-7.

Guimaraes, R.N., E.R.B. de Souza, R.V. Naves, A.P.C. de Melo, and A.R. Neto. 2019. Vegetative propagation of pequi (souari nut) by cutting. Cienc. Rural 49. doi: 10.1590/0103$8478 \mathrm{cr} 20180579$.

Gulen, H., Y. Erbil, and A. Eris. 2004. Improved rooting of Gisela-5 softwood cuttings following banding and IBA application. HortScience 39:1403-1405, doi: 10.21273/Hortsci.39.6.1403.

Harfouche, A., N. Baoune, and H. Merazga. 2007. Main and interaction effects of factors on softwood cutting of white poplar (Populus alba L.). Silvae Genet. 56:287-294, doi: 10.1515/sg2007-0041.

Hechmi, M., M. Khaled, S. Abed, A. El-Hassen, R. Faiez, and A. Mhamed. 2013. Performance of olive cuttings (Olea europaea L.) of different cultivars growing in the agro-climatic conditions of Al-Jouf (Saudi Arabia). Amer. J. Plant Physiol. 8:41-49, doi: 10.3923/ajpp.2013.41.49.

Justamante, M.S., S. Ibanez, J. Villanova, and J.M. Perez-Perez. 2017. Vegetative propagation of argan tree (Argania spinosa (L.) Skeels) using in vitro germinated seeds and stem cuttings. Scientia Hort. 225:81-87, doi: 10.1016/j.scienta. 2017.06.066.

Kareem, A., M.J. Jaskani, B. Fatima, and B. Sadia. 2013. Clonal multiplication of Guava through softwood cuttings under mist conditions. Pak. J. Agr. Sci. 50:23-27, doi: 10.1016/j.agee.2013. 01.009 .

Kitajima, M., I. Mori, K. Arai, N. Kogure, and H. Takayama. 2006. Two new tryptamine-derived alkaloids from Chimonanthus praecox $f$. concolor. Tetrahedron Lett. 47:3199-3202, doi: 10.1016/j.tetlet.2006.03.047.

Li, Z., Y. Jiang, D. Liu, J. Ma, J. Li, M. Li, and S. Sui. 2018a. Floral scent emission from Nectaries in the adaxial side of the innermost and middle petals in Chimonanthus praecox. Intl. J. Mol. Sci. 19:3278, doi: 10.3390/ijms19103278.

Li, B., F.R. Lin, C. Lu, Q.F. Cai, Y.Q. Zheng, and R. Liu. 2018b. Propagation method for soft cuttings of Liriodendron. Bangl. J. Bot. 47:769-778. https://www.researchgate.net/publication/329246407.

Ling, W.X., G. Zhu, and Z. Zhong. 2013. Effect of Iba on Rooting from Softwood Cuttings of 'Tetraploid Locust' and Associated Biochemical Changes. Pak. J. Bot. 45:1801-1806. https:// www.researchgate.net/publication/287469395.

Liu, J., X. Zhai, and Q. Wang. 2001. Study of wintersweet cuttage breeding technology. J. Henan Univ. (Natural Science) 31(3):31873188, doi: 10.15991/j.cnki.411100.2001.03.024.

Liu, D.F., J. Ma, J.F. Yang, T.V. Nguyen, H.M. Liu, R.W. Huang, S.Z. Sui, and M.Y. Li. 2014. Mining simple sequence repeat and single nucleotide polymorphism markers in a transcriptomic database of wintersweet (Chimonanthus praecox). HortScience 49:1360-1364, doi: 10. 21273/Hortsci.49.11.1360.

Mori, Y., F. Miyahara, Y. Tsutsumi, and R. Kondo. 2011. Effects of combinational treatment with ethephon and indole-3-butyric acid on adventitious rooting of Pinus thunbergii cuttings. Plant Growth Regulat. 63:271-278, doi: 10. 1007/s10725-010-9524-3.

Muthukumaran, P., T. Sathishkumar, M. Alamelumangai, J. Dhanalakshmi, M. Mathumitha, and R.S. Renganayaki. 2018. Extraction and antioxidant activity of flavonoids from seed coat of Borassus flabellifer Linn using orthogonal array $\left(\mathrm{L}_{16}\left(4^{(4)}\right)\right)$. Indian J. Pharm. Sci. 80:46-51, doi: 10.4172/pharmaceutical-sciences.1000329.

Ranil, R.H.G., H.M.L. Niran, M. Plazas, R.M. Fonseka, H.H. Fonseka, S. Vilanova, I. Andujar, P. Gramazio, A. Fita, and J. Prohens. 2015. Improving seed germination of the eggplant rootstock Solanum torvum by testing multiple factors using an orthogonal array design. Scientia Hort. 193:174-181, doi: 10.1016/j.scienta.2015.07.030.

Rao, R.S., C.G. Kumar, R.S. Prakasham, and P.J. Hobbs. 2008. The taguchi methodology as a statistical tool for biotechnological applications: A critical appraisal. Biotechnol. J. 3:510-523, doi: 10.1002/biot.200700201.

Sadr, S., V. Mozafari, H. Shirani, H. Alaei, A.T. Pour, and A.R. Behjat. 2019. Control of pistachio endocarp lesion by optimizing the concentration of some nutrients using taguchi method. Scientia Hort. 256. doi: 10.1016/j.scienta.2019.108575.

Saranga, J. and R. Cameron. 2007. Adventitious root formation in Anacardium occidentale L. in response to phytohormones and removal of roots. Scientia Hort. 111:164-172, doi: 10.1016/j.scienta.2006.10.010.

Shi, C.F., Z.X. Ju, and D.H. Wang. 2019. Application of flower and shrub in landscape planning and design and study on cutting propagation technology. Arch. Latinoam. Nutr. 69:302-310.

Shibuya, T., S. Tsukuda, A. Tokuda, S. Shiozaki, R. Endo, and Y. Kitaya. 2013. Effects of warming basal ends of Carolina poplar (Populus $\mathrm{x}$ canadensis Moench.) softwood cuttings at controlled low-air-temperature on their root growth and leaf damage after planting. J. Forest Res-Jpn. 18:279-284, doi: 10.1007/s10310012-0343-4.

Stefancic, M., D. Vodnik, F. Stampar, and G. Osterc. 2007. The effects of a fogging system on the physiological status and rooting capacity of leafy cuttings of woody species. Trees 21:491-496, doi: 10.1007/s00468-006-0121-z.

Sulusoglu, M. and A. Cavusoglu. 2010. Vegetative propagation of Cherry laurel (Prunus laurocerasus L.) using semi-hardwood cuttings. Afr. J. Agr. Res. 5:3196-3202, doi: 10.5897/AJAR10.554.

Tang, A. and M. Tian. 2010. Breaking combinational dormancy in seeds of Chimonanthus praecox L. Seed Sci. Technol. 38:551-558, doi: 10.15258/sst.2010.38.3.03.

Tarrago, J., P. Sansberro, R. Filip, P. Lopez, A. Gonzalez, C. Luna, and L. Mroginski. 2005. Effect of leaf retention and flavonoids on rooting of Ilex paraguariensis cuttings. Scientia Hort. 103:479-488, doi: 10.1016/j.scienta. 2004.07.004.

Thomas, P. and J.W. Schiefelbein. 2004. Roles of leaf in regulation of root and shoot growth from single node softwood cuttings of grape (Vitis vinifera). Ann. Appl. Biol. 144:27-37, doi: 10.1111/j.1744-7348.2004.tb00313.x.

van Telgen, H.J., B. Eveleens-Clark, and N.G. Victoria. 2007. Improving rooting uniformity in rose cuttings. Propag. Ornam. Plants 7:190194, doi: 10.1016/j.postharvbio.2007.05.012.

Zhao, K.G., M.Q. Zhou, L.Q. Chen, D.L. Zhang, and G.W. Robert. 2007. Genetic diversity and discrimination of Chimonanthus praecox (L.) link germplasm using ISSR and RAPD markers. HortScience 42:1144-1148, doi: 10.21273/Hortsci.42.5.1144.

Zhao, X.Y., H.Q. Zheng, S.W. Li, C.P. Yang, J. Jiang, and G.F. Liu. 2014. The rooting of poplar cuttings: A review. New For. 45:21-34, doi: 10.1007/s11056-013-9389-1. 